\title{
Penerapan Pendekatan Kontekstual Berbasis REACT Untuk Meningkatkan Hasil Belajar Fisika Pada Siswa Kelas X SMA Negeri 8 Palu
}

\author{
Nina Muzdalifa \\ Email: muzdalifa_nina@yahoo.com \\ Program Studi Pendidikan Fisika, Jurusan Pendidikan MIPA, Universitas Tadulako \\ Jl. Soekarno Hatta KM. 9, Kampus Bumi Tadulako Tondo Palu - Sulawesi Tengah
}

\begin{abstract}
Abstrak - Telah dilakukan penelitian yang bertujuan untuk meningkatkan hasil belajar fisika siswa melalui penerapan pendekatan kontekstual berbasis REACT. Penelitian ini melibatkan 25 siswa kelas $X_{C}$ SMAN 8 Palu, dilakukan dalam dua siklus dengan materi pokok gerak lurus. Penerapan pendekatan kontekstual berbasis REACT dapat meningkatkan hasil belajar. Hal ini dapat dilihat dari hasil observasi aktivitas guru dan siswa dalam kegiatan pembelajaran siklus I dan siklus II meningkat dari kategori cukup baik ke kategori baik. Kemudian peningkatan fase REACT pada siklus I dan siklus II meningkat dari kategori baik menjadi sangat baik. Berdasarkan hasil tes pada siklus I diperoleh ketuntasan klasikal $72,00 \%$ dan daya serap klasikal sebesar $70.13 \%$. Sedangkan pada siklus II diperoleh ketuntasan klasikal $80.00 \%$ dan daya serap klasikal sebesar $77.07 \%$. Ketuntasan belajar klasikal yang diperoleh pada siklus II telah memenuhi standar ketuntasan belajar klasikal yang telah ditetapkan yaitu di atas 70\%. Penelitian ini dapat disimpulkan bahwa dengan penerapan pendekatan kontekstual berbasis REACT dapat meningkatkan hasil belajar fisika pada siswa kelas $\mathrm{X}_{\mathrm{c}}$ SMA Negeri 8 Palu
\end{abstract}

Kata Kunci: Pendekatan Kontekstual, Pembelajaran REACT, Hasil Belajar Fisika

\section{PENDAHULUAN}

Pendidikan tidak hanya ditekankan pada penguasaan materi, tetapi juga ditekankan pada penguasaan keterampilan. Siswa juga harus memiliki kemampuan serta keterampilan untuk berbuat sesuatu dengan menggunakan proses dan prinsip keilmuan yang telah dipelajari. Rendahnya hasil belajar dipengaruhi oleh kurangnya siswa yang bersikap aktif saat proses pembelajaran sehingga siswa sulit memahami materi yang diajarkan karena sebagian besar hanya mendengarkan penjelasan guru tanpa terlibat langsung dalam kegiatan pembelajaran.

Pada dasarnya untuk mencapai hasil belajar yang optimal tentu tidak terlepas dari proses pembelajaran itu sendiri, sehingga penilaian proses juga perlu diperhatikan. Oleh karena itu, penilaian harus mencakup atas tiga aspek yaitu aspek kognitif, afektif serta psikomotor.

Faktanya yang terjadi di SMA Negeri 8 Palu, penilaian pembelajaran fisika hanya mencakup aspek kognitif saja. Guru masih menggunakan model penilaian yang merujuk kepada ukuranukuran yang dipaksakan seperti tes pilihan ganda, isian, benar salah, menjodohkan serta bentuk-bentuk serupa lainnya yang biasa digunakan dalam pendidikan.
Pelaksanaan penilain yang tertuju pada proses pembelajaran atau yang sering disebut penilaian berbasis kinerja atau penilaian langsung, guru dapat langsung mengukur keterampilan serta kemampuan dari setiap siswanya. Penerapan model penilaian berbasis kinerja mengharuskan siswa untuk bekerja atau melakukan sehingga siswa dapat menganalisis serta menarik kesimpulan tentang hal tersebut.

Guru masih mengabaikan suatu penilaian yang dilakukan secara langsung atau yang disebut penialaian autentik, karena mereka beranggapan bahwa hasil belajar dapat diukur melalui tes di setiap akhir pertemuannya di kelas padahal penilaian autentik juga dapat mengukur hasil belajar berdasarkan penugasan atau kinerja, sebab ketika melakukan penilaian proses, banyak kegiatan yang akan lebih jelas apabila dinilai langsung. Umpamanya kemampuan atau keterampilan melaksanakan percobaan, begitu pula menilai sikap atau perilaku siswa terhadap sesuatu atau pada saat melakukan sesuatu.

Pendapat lain sehingga guru tidak tertarik dan tidak mau menggunakan penilaian bebasis kinerja karena menurut mereka bahwa melakukan penilaian autentik membuang waktu dan energi serta terlalu mahal, apalagi penilaian autentik perlu dirancang dengan baik. 
Pendapat tersebut tentunya tidak benar. Menilai kinerja dengan tes tertulis tentu tidak valid, karena tidak mengukur apa yang dinilai. Kinerja perlu dinilai pada saat kegiatannya sedang berlangsung.

Jika penilaian kinerja dilakukan terhadap sejumlah siswa dan tidak dirancang dulu atau dilakukan asal-asalan, tentu hasilnya tidak dapat dipertanggungjawabkan karena tidak konsisten. Dengan demikian, kita mungkin tidak berlaku adil terhadap sejumlah siswa dalam menilai kinerja mereka.

Selain rendahnya hasil belajar, permasalahan lain yang diperoleh di lapangan berdasarkan hasil wawancara pada salah seorang guru fisika di SMA Negeri 8 Palu adalah kurangnya konsentrasi siswa saat belajar sehingga sulit untuk memahami materi yang diberikan. Selain itu, sumber belajar yang masih terbatas, hal tersebut ditandai dengan tidak semua siswa memiliki buku, sehingga yang terjadi adalah siswa sekedar melihat, mendengar dan mencatat.

Adapun daftar nilai yang merupakan hasil belajar siswa semester ganjil di SMA Negeri 8 Palu tahun ajaran 2012/2013 seperti yang ditunjukkan pada tabel 1.1, menunjukkan bahwa prestasi belajar siswa fisika kelas X SMA negeri 8 Palu masih tergolong rendah. Hal ini memberi kesan akan sulitnya pelajaran fisika dan kurangnya antusias siswa untuk belajar sehingga menimbulkan kejenuhan dan bosan pada siswa itu sendiri. Nilai batas standar ketuntasan yang ditentukan adalah 70 .

Tabel 1. Nilai Rata-rata Ujian Fisika Semester Ganjil Kelas X SMA Negeri 8 Palu Tahun Ajaran 2012/2013.

\begin{tabular}{|c|c|c|}
\hline No & Kelas & Nilai Rata-rata Fisika \\
\hline 1. & $\mathrm{X}_{\mathrm{A}}$ & 65,1 \\
\hline 2. & $\mathrm{X}_{\mathrm{B}}$ & 70,4 \\
\hline 3. & $\mathrm{X}_{\mathrm{C}}$ & 60,1 \\
\hline
\end{tabular}

Sumber : SMA Negeri 8 Palu

Sehubungan dengan permasalahan yang dikemukakan di atas, maka peneliti menduga bahwa metode pembelajaran yang digunakan selama ini belum efektif, yang menyebabkan rendahnya hasil belajar siswa khususnya siswa kelas X SMA Negeri 8 Palu. Oleh karena itu, diperlukan adanya penggunaan suatu bentuk metode pembelajaran yang dapat meningkatkan hasil belajar fisika siswa.
ISSN 23383240

Adapun cara yang dilakukan untuk mengatasi permasalahan tersebut adalah dengan melakukan penerapan pendekatan kontekstual berbasis REACT (Relating, Experiencing, Applying, Coorperating, Transfering). Berdasarkan penelitian sebelumnya [5] berjudul Pengembangan Instrumen Penilaian Autentik Berbasis Kinerja dalam Pembelajaran Fisika Model REACT menyatakan bahwa pembelajaran REACT mampu meningkatkan pemahaman siswa terhadap materi sehingga dapat meningkatkan hasil belajar karena REACT (Relating, Experiencing, Applying, Coorperating, Transfering) adalah salah satu strategi yang ada dalam pendekatan kontekstual yang meliputi kegiatan mengaitkan, mengalami, menerapkan, berkerja sama, dan mentransfer dalam proses belajar siswa.

Pentingnya penerapan pendekatan kontekstual didasari dengan adanya fakta di lapangan bahwa sebagian siswa masih kurang mampu memahami proses-proses fisika yang mereka peroleh di sekolah, untuk kemudian menghubungkan, mengaplikasikan, serta memanfaatkannya di kehidupan nyata. Menerapkan pendekatan kontekstual berbasis REACT, siswa akan lebih mudah untuk memahami materi yang akan mereka pelajari, karena proses pembelajaran yang menghadirkan/mengaitkan masalah-masalah yang mereka temukan di kehidupan sehari-hari, sehingga siswa akan mampu menganalisis, akan lebih mudah untuk menghubungkannya kedalam pembelajaran, mampu mengaplikasikan serta memanfaatkannya di kehidupan nyata.

\section{METODOLOGI PENELITIAN}

\section{A. Gambar dan Tabel}

Adapun jenis penelitian ini merupakan penelitian tindakan kelas (classroom action research) yaitu penelitian yang dilakukan dengan penekanan pada penyempurnaan atau peningkatan proses dan praktis pembelajaran. PTK berfokus pada kelas atau pada proses belajar mengajar yang terjadi di kelas. Penerapan pendekatan kontekstual berbasis REACT dilakukan di kelas Xc SMAN 8 Palu pada tanggal 27 Agustus sampai 19 September 2013 dengan jumlah siswa 25 orang yang terdiri dari 12 orang laki-laki dan 13 orang perempuan.

Penelitian ini dilaksanakan bersiklus yang mengacu pada model Kurt Lewin yang dikembangkan oleh Kemmis dan Mc.Taggart [1] yang meliputi empat kegiatan utama yang ada 
pada setiap siklus yaitu: (1) perencanaan (2) pelaksanaan tindakan (3) observasi dan (4) refleksi. Penggunaan model ini dikarenakan alur yang digunakan cukup sederhana dan mudah untuk dilaksanakan. Berikut adalah gambar alur pelaksanaan tindakan yang dimaksud.

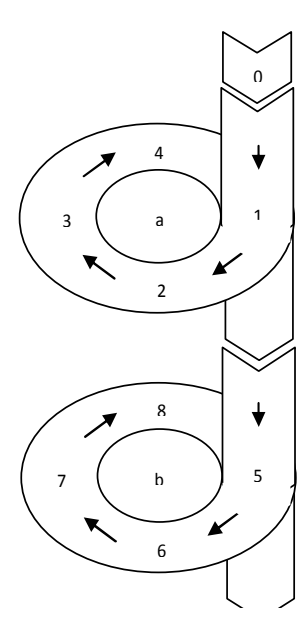

Keterangan:

0: Pra Tindakan

1: Rencana siklus 1

2: pelaksanaan

tindakan kelas

3: Observasi siklus 1

4: Refleksi siklus 1

5: Rencana siklus 2

6: pelaksanaaan

tindakan kelas

7: Observasi siklus 2

8: Refleksi siklus 2

a: Siklus 1

b: Siklus 2

Gambar (1) Diagram Alur Desain Penelitian Model Kemmis dan Mc Taggart.

Secara umum kegiatan penelitian ini dapat dibedakan dalam dua tahap, yaitu tahap pratindakan dan tahap pelaksanaan tindakan.

1) Tahap Pratindakan

- Penelitian ini dimulai dengan tindakan pendahuluan atau refleksi awal. Kegiatan yang dilakukan pada tahap ini adalah observasi lapangan, dialog dengan guru fisika kelas Xc SMA Negeri 8 Palu. Hasil refleksi dijadikan perencanaan pelaksanaan penelitian.

- Menentukan subjek penelitian yang terdiri dari 25 siswa orang dengan 12 laki-laki dan 13 orang perempuan.

- Menyiapkan tes awal

- Membentuk kelompok belajar siswa yang sifatnya heterogen (baik dari segi kemampuan fisika maupun jenis kelamin) berdasarkan pada hasil tes awal dan informasi dari guru fisika SMA Negeri 8 Palu.

2) Tahap Pelaksanaan Tindakan

Pelaksanaan tindakan dilakukan dalam siklus berulang. Tiap siklus terdiri dari empat fase sebagai berikut : (1) Perencanaan, (2) Pelaksanaan Tindakan, (3) Observasi, dan (4) Analisis dan Refleksi. Adapun kegiatankegiatan dalam setiap siklus yang terdiri dari empat fase tersebut adalah sebagai berikut : Siklus I

a. Perencanaan
ISSN 23383240

Pada tahap ini peneliti menyusun perencanaan sebagai berikut:

- Membuat rencana pelaksanaan pembelajaran tentang materi yang akan diajarkan dengan dalam pembelajaran kontekstual dengan strategi REACT.

- Membuat skenario pembelajaran kontekstual dengan strategi REACT.

- Menyiapkan materi pembelajaran yang akan dilaksanakan di kelas.

- Menyediakan alat bantu mengajar yang berhubungan dengan pembelajaran kontekstual.

- Membuat lembar penilaian Afektif siswa dan Psikomotor siswa.

- Membuat lembar observasi guru dan siswa yang akan digunakan pada saat mengobservasi kegiatan pembelajaran di kelas.

- Merancang alat evaluasi berupa tes hasil belajar untuk mengetahui tingkat penguasaan materi yang telah diajarkan. Dilakukan pada akhir tindakan tiap siklus berakhir. Adapun tes hasil belajarnya berupa tes pilihan ganda.

b. Pelaksanaan Tindakan

Kegiatan yang dilaksanakan bersiklus. Tatap muka dua kali pertemuan, kemudian dilakukan tes hasil belajar tiap siklus. Pelaksanakan pembelajaran sesuai skenario pembelajaran yang telah dirancang.

c. Observasi

Kegiatan yang dilakukan pada tahap ini adalah mengobservasi pelaksanaan tindakan dengan menggunakan lembar observasi. Pada saat berlangsungnya kegiatan pembelajaran, dilakukan pengamatan terhadap aktivitas siswa dan guru. Untuk aktivitas siswa, yang dapat nilai yaitu aspek afektif, aspek psikomotor, pemberian tes akhir tindakan dan untuk menindak lanjuti hasil observasi dan tes akhir tindakan diberikan angket berupa respon siswa terhadap subjek penelitian serta aktifitas siswa dalam belajar.

Sedangkan aktivitas guru, alat ukur yang digunakan yaitu lembar observasi yang disediakan.

d. Refleksi

Kegiatan yang dilakukan pada tahap ini adalah menganalisis data yang diperoleh pada tahap observasi dan hasil tes. Berdasarkan hasil analisis data dilakukan refleksi guna melihat 


\section{Jurnal Pendidikan Fisika Tadulako (JPFT)}

Vol. 1 No. 2

kekurangan-kekurangan yang terjadi pada saat pembelajaran siklus 1 diterapkan. Hasil refleksi yang telah dilakukan pada tahap ini dijadikan awal untuk merencanakan siklus berikutnya.

Siklus II

Perbedaan antara pelaksanaan tindakan siklus I dengan pelaksanaan tindakan siklus II hanyalah pada materi ajar dan hal-hal yang dianggap kurang dari siklus I, dan kemudian diperbaiki untuk diterapkan pada siklus II.

\section{HASIL DAN PEMBAHASAN}

Berikut adalah hasil kegiatan observasi aktivitas siswa dapat dilihat persentase ketercapaian pembelajaran REACT dari setiap langkah pembelajaran pada siklus I.

1. Relating sebesar $87,5 \%$ kategori baik.

2. Experencing sebesar $75 \%$ kategori cukup.

3. Applying sebesar $75 \%$ kategori cukup.

4. Cooperating sebesar $62,5 \%$ kategori kurang.

5. Transfering sebesar $62,5 \%$ kategori kurang. Berikut adalah hasil kegiatan observasi aktivitas guru dapat dilihat persentase ketercapaian pembelajaran REACT dari setiap langkah pembelajaran pada siklus I.

1. Relating sebesar $62,5 \%$ kategori kurang

2. Experencing sebesar $75 \%$ kategori cukup

3. Applying sebesar $70,83 \%$ kategori cukup

4. Cooperating sebesar $75 \%$ kategori cukup

5. Transfering sebesar $62,5 \%$ kategori kurang Berikut hasil kegiatan observasi aktivitas siswa dapat dilihat persentase ketercapaian menggunakan pendekatan kontekstual berbasis REACT dari setiap langkah pembelajaran sudah meningkat pada siklus II.

1. Relating sebesar $100 \%$ kategori sangat baik

2. Experencing sebesar $87,5 \%$ kategori baik

3. Applying sebesar $95,83 \%$ kategori sangat baik

4. Cooperating sebesar $93,75 \%$ kategori sangat baik

5. Transfering sebesar $87,5 \%$ kategori baik

Berikut hasil kegiatan aktivitas guru dapat dilihat persentase ketercapaian penggunaan pendekatan kontekstual berbasis REACT dari setiap langkah pembelajaran pada siklus II.

1. Relating sebesar $87,5 \%$ kategori baik

2. Experencing sebesar $100 \%$ kategori sangat baik
ISSN 23383240

3. Applying sebesar $91,67 \%$ kategori sangat baik

4. Cooperating sebesar 93,75\% kategori sangat baik

5. Transfering sebesar $87,5 \%$ kategori baik

Peningkatan hasil belajar yang terjadi pada siklus I ke siklus II tidak semata-mata dikatakan berhasil karena nilai akhir yang dicapai meningkat. Namun, disebabkan karena siswa lebih senang dalam proses pembelajaran dengan penerapan pendekatan kontekstual berbasis REACT dengan dibantu bimbingan guru, sehingga siswa lebih mudah mengingat dan memahami materi yang diajarkan.

Menerapkan pembelajaran pendekatan kontekstual berbasis REACT, siswa lebih berkonsentrasi serta lebih aktif bertanya ketika apa yang dipelajari sesuai dengan kehidupan sehari-hari (Relating), serta siswa lebih antusias mencari sendiri hal yang tidak dipahaminya melalui kegiatan merumuskan hipotesis (Experiencing), dengan kata lain siswa memahami teknis pembelajaran dengan menerapkan pendekatan kontekstual berbasis REACT. Siswa lebih aktif dalam diskusi dan kerjasama dengan teman kelompoknya (Cooperating), meliputi keaktifan siswa dalam mengisi, menjawab serta menyelesaikan LKS bersama kelompoknya. Peningkatan yang sama juga ditunjukkan pada saat proses pembelajaran yaitu dengan lebih terampil lagi dalam kegiatan pengamatan dan bereksperimen terhadap penerapan hipotesis (Applying), dan siswa mengungkapkan penerapan materi dengan baik pada fase Transfering.

Dari hasil kegiatan guru dapat dilihat pada persentase ketercapaian penggunaan REACT dari setiap langkah pembelajaran meningkat. Kenaikan aktivitas guru dari siklus I ke siklus II disebabkan karena guru terus-menerus berusaha untuk meningkatkan motivasi dan bimbingan kepada siswa serta mampu memaksimalkan waktu yang ada.

Berdasarkan data hasil belajar dan observasi guru dan siswa selama kegiatan pembelajaran di tiap siklus, diambil kesimpulan bahwa aktivitas siswa selama mengikuti proses pembelajaran siklus I dan II menurut pengamat sudah baik. Hal ini dapat dilihat dari 
ISSN 23383240

grafik peningkatannya pada Gambar 2 .

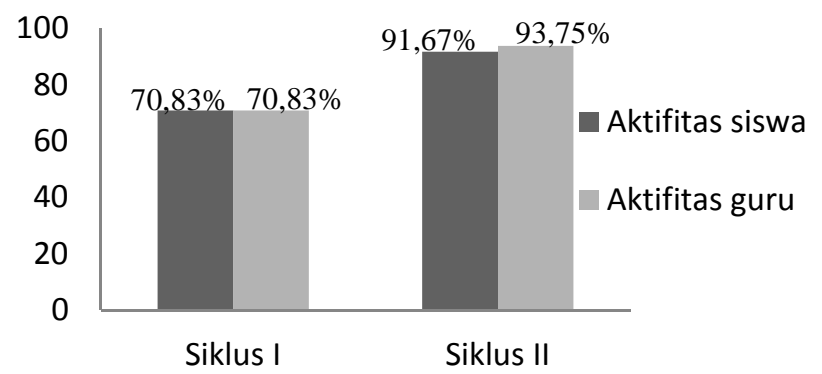

Gambar 2. Grafik Peningkatan Aktivitas Siswa dan Guru

Sikap dilakukan pada saat tindakan sedang berlangsung. Pada awal pembelajaran, keaktifan siswa masih belum nampak. Hal ini disebabkan karena siswa belum terbiasa dengan pembelajaran berbasis REACT. Namun pada pertemuan berikutnya, siswa sudah mulai aktif dalam proses pembelajaran. Hal ini dapat dilihat pada gambar 3 .

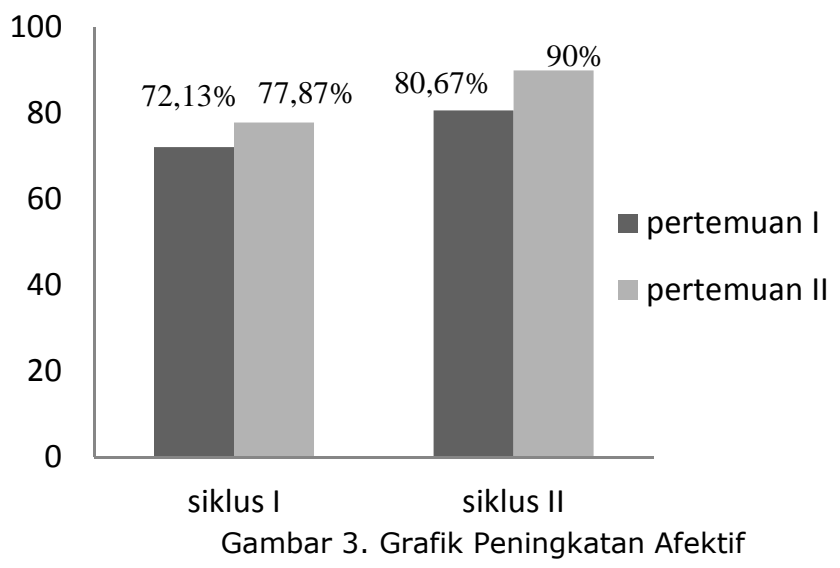

Aktivitas psikomotor siswa setiap pertemuannya pada siklus I masih kurang dan untuk pertemuan pada siklus II sudah baik. Hal ini dapat dilihat pada gambar 4 .

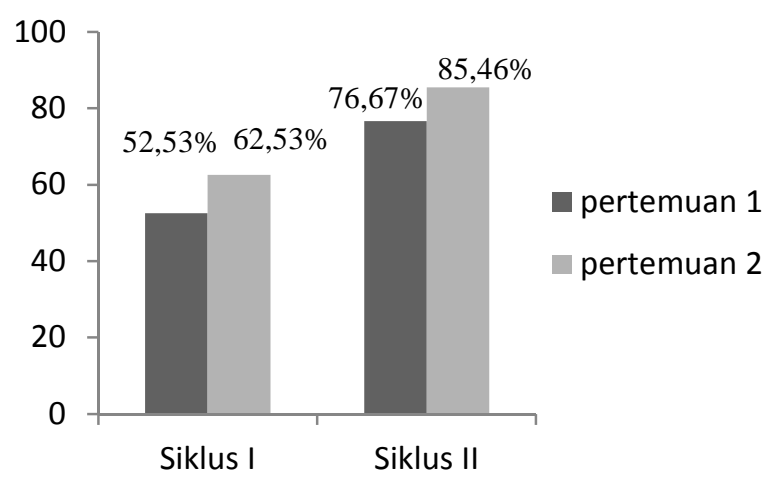

Gambar 4. Grafik Peningkatan Psikomotor
Berdasarkan hasil penelitian yang dilakukan, memberikan informasi bahwa model pembelajaran yang digunakan merupakan salah satu alternatif untuk meningkatkan hasil belajar fisika, sebagaimana dapat dilihat pada Gambar5.

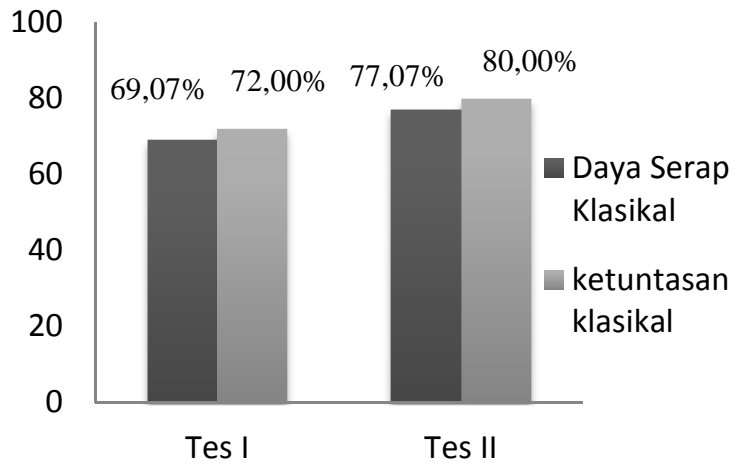

Gambar 5. Grafik Peningkatan Hasil Belajar

Hasil yang diperoleh pada siklus II lebih baik dari siklus I. Peningkatan ini terjadi karena kekurangan-kekurangan yang terdapat pada siklus I dapat diminimalisir. Peningkatan hasil yang signifikan dapat dilihat pada ketuntasan belajar klasikal yang mencapai $80,00 \%$ atau terdapat 20 siswa yang tuntas dari 25 siswa yang mengikuti ujian.

Pola pembelajaran dengan menerapkan pendekatan kontekstual berbasis REACT dapat meningkatkan daya pikir siswa, dapat mengukur dan melihat perbedaan kemampuan serta keterampilan siswa pada kegiatan melakukan pengamatan dan eksperimen (penilaian autentik), karena melalui penilaian proses inilah dapat dilihat siswa yang memiliki kemampuan serta keterampilan yang lebih dibandingkan siswa lainnya, memberikan kesempatan kepada siswa untuk lebih memahami suatu kasus atau masalah, mendorong siswa untuk memperhatikan pendapat orang lain pada (Cooperating).

Ketika siswa diberikan informasi untuk melakukan kegiatan Relating, maka siswa akan melakukan interaksi seperti menerima informasi dan menghubungkan apa yang hendak dipelajari dengan pengalaman atau kehidupan nyata sehingga tercipta motivasi yang baik.

Ketika siswa diberikan permasalahan yang berupa soal atau sejenisnya yang menuntut mereka menjawabnya secara mandiri, maka setelah siswa mendengarkan soal yang diberikan guru tersebut, siswa akan bertanya pada dirinya sendiri tentanng konsep-konsep yang dibutuhkan untuk menyelesaikan soal 
tersebut. Karena siswa telah belajar dalam konteks penemuan, dan penciptaan (Experencing). Ini berarti bahwa pengetahuan yang diperoleh siswa melalui pembelajaran (Applying) tercapai pula. kognitifnya adalah untuk memahami dan menyelesaikan soal. Siswa akan mengulangi menanyakan soal kuis dan mencari konsep-konsep yang dibutuhkan agar mampu menjawab pertanyaannya sendiri atau yang diberikan oleh guru berdasarkan pengalaman belajar (Transfering).

\section{KESIMPULAN}

Kesimpulan yang dapat diambil dari penelitian ini bahwa penerapan pendekatan kontekstual berbasis REACT dapat memberikan pengalaman kepada siswa, sehingga dapat meningkatkan hasil belajar fisika. Hasil pelaksanaan tindakan siklus II diperoleh ketuntasan belajar klasikal mencapai $80 \%$ dan daya serap klasikal $77,07 \%$, dari perolehan tersebut menunjukkan hasil lebih baik dari siklus I.

\section{DAFTAR PUSTAKA}

[1] Arikunto, S., Suharjono dan Supardi. (2008). Penelitian Tindakan Kelas. Jakarta: Bumi Aksara.

[2] Moon T.R. et al.(2005).Development of authentic assessments for the middle school classroom. The Journal of Secondary Gifted Education Vol XVI No.2/3 Winter/Spring

[3] Mueller, J. (2006). Authentic Assessment. North Central College. Tersedia. http://jonatan.muller.faculty.noctrl.edu/toolbox/whatis ist.htm

[4] Wiggins, G. (2005). The Case for Authentic Assessment. ERIC Digest ED238611 (online). Tersedia. http://www.ed.go/database/ERICDigests/ed238611.ht $\underline{\mathrm{ml}}$

[5] Wulandari, Dewi. (2012). Pengembangan Instrumen Penilaian Autentik Berbasis Kinerja dalam Pembelajaran Fisika Model REACT. (online). Tersedia. http://ejournal.unp.ac.id. email:d3w_wul4nd4r1@yahoo.com. 